2016-01-01

\title{
Film as architectural theory
}

\section{Troiani, I}

http://hdl.handle.net/10026.1/16409

10.1080/20507828.2016.1239965

Architecture and Culture

All content in PEARL is protected by copyright law. Author manuscripts are made available in accordance with publisher policies. Please cite only the published version using the details provided on the item record or document. In the absence of an open licence (e.g. Creative Commons), permissions for further reuse of content should be sought from the publisher or author. 


\section{Architecture and Culture}

\section{Architecture and Culture}

\section{Film as Architectural Theory}

\section{Igea Troiani \& Alison Kahn}

To cite this article: Igea Troiani \& Alison Kahn (2016) Film as Architectural Theory, Architecture and Culture, 4:3, 485-498, DOI: 10.1080/20507828.2016.1239965

To link to this article: http://dx.doi.org/10.1080/20507828.2016.1239965

$$
\text { 曲 Published online: } 11 \text { Nov } 2016 .
$$

Submit your article to this journal ๔

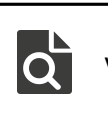

View related articles $\longleftarrow$

View Crossmark data ¿ 


\section{ARCHTECTURE AND CULTURE}

\section{Igea Troiani}

School of Architecture, Design and Environment, Oxford Brookes University, Oxford, UK

itroiani@brookes.ac.uk

\section{Alison Kahn}

Film Production, School of Arts, Oxford Brookes University, Oxford, UK

akahn@brookes.ac.uk

Keywords: architectural theory, filmmaking, anthropology, practicebased research

Volume 4/Issue 3

November 2016

pp 485-498

DOI: $10.1080 / 20507828$

2016.1239965

No potential conflict of interest was reported by the author.

Reprints available directly from the publishers. Photocopying permitted by licence only.

(c) 2016 Informa UK Limited, trading as Taylor \& Francis Group

\section{Film as Architectural Theory Igea Troiani and Alison Kahn}

ABSTRACT Publications on architectural theory have predominantly taken on the form of text-based books, monographs, and articles. With the rise of transdisciplinary and practice-based research in architecture, new opportunities are opening up for other forms of architectural theory, such as film-based mediums, which promise to expand and alter the convention of the written practice of theory. Two possible types of filmic theory are presented here. One follows the method of ethnographic documentary filmmaking inspired by Sarah Pinkfilm-based mediums, which promise to expand and alter thellows the line of art house filmmaking inspired by Kathryn Rameyyn Rameyg inspired by Sarah Pinkfilm-based mediums, which promise to expand ae to expand ad mediums, which promise to expand a convention of the written practice of theory. or constructing knowledge, new discourses on filmic theory can be opened up. It is argued here that film as architectural theory is part of this new discourse, broadening the audience'u engagement with architecture through not only "readership" but also "viewership." 


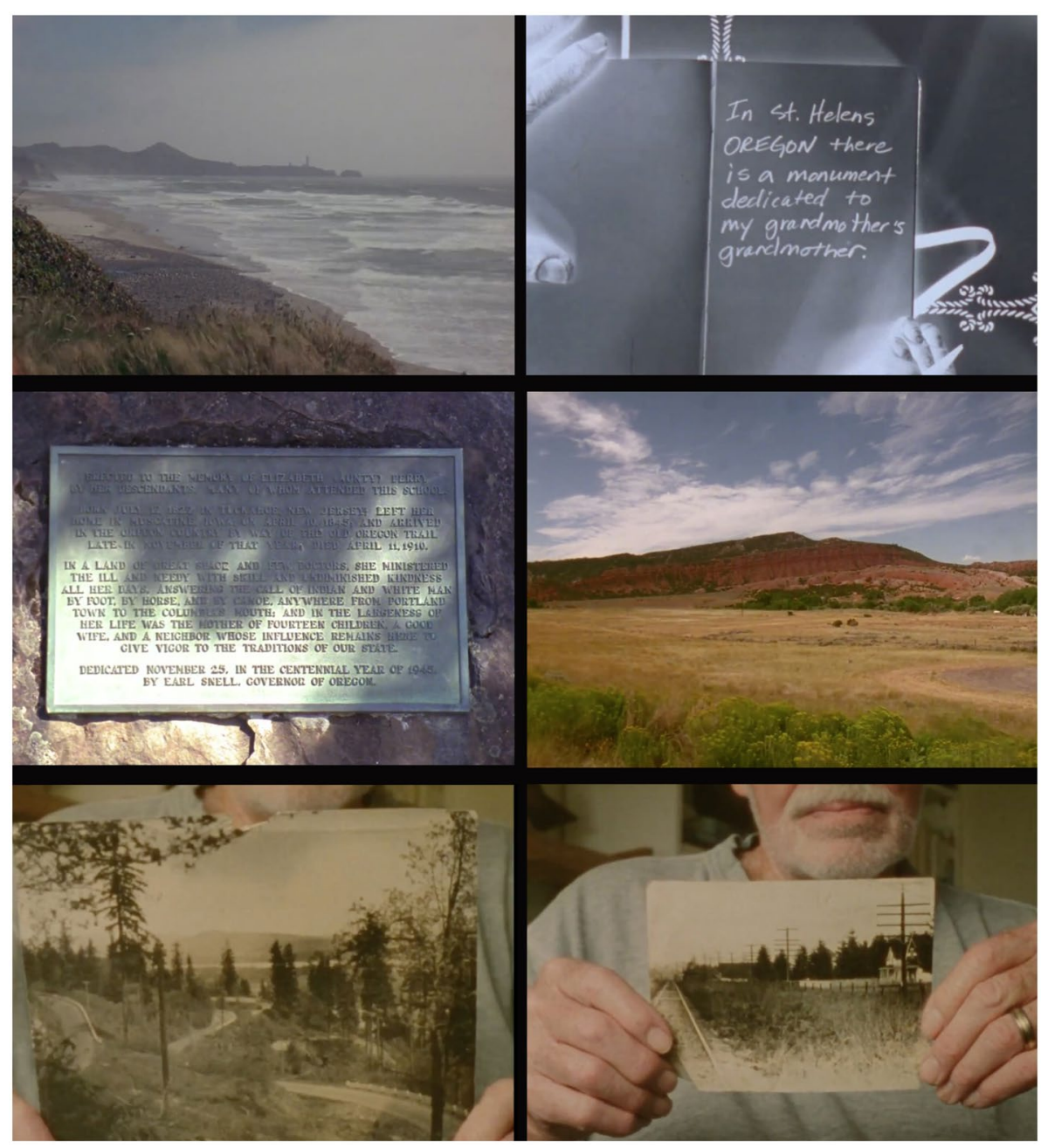

Figure 1

Stills from Kathryn Ramey's video WEST: What I Know about Her (2012). For the full video, see https://www.youtube.com/ watch?v=euuQGqfF7Tg (accessed August 30, 2016).

\section{Architecture and Its "Theoretical Meltdown(s)"}

Since the decline of hegemonic modernism, architects and architectural theoreticians have claimed that architecture has been going through a series of "theoretical meltdowns" or near-death experiences. In "Meeting the New Boss: After the Death of Theory," Christopher Hight asserts that the last issue of Assemblage (April 2000) signaled the moment when critical theory finally lost its ability to be generative and productive. Debilitated by overt academicization, theory has been drowned in too many words, distancing itself further from, rather than progressing, practice. ${ }^{1}$ Helen Castle explains this moment of theoretical meltdown: "with the loss of conviction in the wider world, architecture has lost its borders as a discipline and theory seems to have lost its pertinence for architecture." Then there is the contention that "theory is obsolete in 
the global marketplace,"3 or that architects should return to a material practice rather than a semiotic one. ${ }^{4}$ The problem, though, is not a total loss in faith in architectural theory since there remains a desire to continue to think in, of, and through architecture. ${ }^{5}$ Instead, some critics argue that architects no longer know how to "act architecturally" since there is a lack of physical conformity between an architectural thought and the reality. ${ }^{6}$ There is a perceived disciplinary crisis in both the imperatives and methodologies for theorizing architecture because its practice has become somewhat limitless; as Luigi Prestinenza Puglisi writes, "anything goes." In this essay, we acknowledge these doubts about the practice and relevance of architectural theory, but at the same time argue that architectural theory is far from becoming obsolete or subservient to the material production of architecture. We contend that architectural theory should expand on how it thinks and concerns itself with new operatives in architectural discourses, new media, and platforms of dissemination beyond traditional methods. What is at stake and what can be gained if we experiment with the constitutive form, medium, and process of architectural theory today?

\section{Architectural Theory Beyond Illustrated Words}

Regardless of the vast range of media and modes of communication in which architectural scholarship could appear, most architectural theory till now remains limited to printed books, monographs, and articles, principally text-based and academic in tone and style. Traditional architectural scholarship as part of the humanities has privileged single authorship over multiple authors and defended a rigorously theoretical style of argument or thesis. This mode of discourse has been characterized by "hegemonic masculinity" that is combative through words. While literary theorists, philosophers, and semioticians have challenged such authority by proclaiming the "death" of single authorship because it "imposes a limit on that text" and its readings, architectural theorists have taken only very small steps to explore the use of other voices. ${ }^{8}$

In the last twenty years, a scant number of architectural writers have been successful in challenging the limits of theory through the use of alternative modes of textual writing such as fiction, creative, or autobiographical writings. There is also a rise in the production of visual essays that tips the balance toward the use of images as the main carrier of the argument where words become supplementary. Yet these works are still published in print or electronic form as books or in journals. With the growing use of digital platforms, audiovisual material is beginning to appear in interactive digital publications in which the newly constructed relation between image and text on screen - as moving image and sound - deconstructs limits of the static frame of a "page." Yet, in the majority of cases, videos or excerpts of films referenced by theoreticians remain supplementary to a written argument or merely evidence for the text. Our interest is in the possibility of an "audiovisual" architectural theory 
that can be conceived as a holistic learning experience of "viewership" beyond the conventional "readership." Here orality and visuality become new research tools, and the audio and visual recordings a new syntax of architectural theory. ${ }^{9}$ Inspired by the philosophies of Jacques Rancière, the discursive practice of architectural theory can expand the narrative form of written words to include audio recordings and/or still or moving images.

In The Future of the Image, Rancière sets out to analyze the visual arts of painting, cinema, and audiovisual installations where "images" and their connections to a narrative or affective end occupy centre stage. ${ }^{10}$ Rancière concludes that artistic images "are [...] operations: relations between a whole and parts; between a visibility and a power of signification and affect associated with it; between expectations and what happens to meet them."11 When an artistic technique is used to create images, such as in a movie, a series of layered exchanges occurs between the image, its resemblance and hyper-resemblance. ${ }^{12}$ It is the “regime of 'imageness,' a particular [...] articulation between the visible and the sayable" that allows a double poetics to occur, "impervious to any narrativization, any intersection of meaning." "According to Rancière, it is through the interchange and blurring between mental and material realities that the regime of images enables discursive practices to be materially embedded and to emancipate spectators as artists constructing knowledge and readings in their own terms.

The reader-spectator of architectural theory in the form of moving images has the potential to occupy a participatory space because the argument is presented purposely through a broader sensorial "page" space. In this space they are offered a degree of freedom, individually and collectively, to interpret the content between the presentation of moving images, audio recording, and supplementary texts. This differs from conventional architectural theory which holds a limited space for the reading of images, which are solely illustrative of the written text. The inclusion of photographs - the equivalent of Rancière's naked images - in architecture books has allowed the reader of architectural theory to access the "visible form of an architectural model" as a way to approximate how one sees with how one experiences. ${ }^{14}$ But multiple ways that visual arts use audios and images, such as in filmmaking, suggest new possibilities for architectural theory to be embedded in sensorial perception and of thinking about architecture beyond the limitation of narrative writing.

Unlike still photographic images, the moving image is able to capture the temporality of bodily and sensorial experiences in and beyond reality. Juhani Pallasmaa points out that "the preconscious perceptual realm, which is experienced outside the sphere of focused vision, seems to be just as important existentially as the focused image." 15 He writes: "Images of one sensory realm feed further imagery in another modality. Images of presence give rise to images of memory, imagination and dream." ${ }^{16}$ This complex, full-body relationship between 
orality, aurality, and visuality in the experience of the world is relevant not only to architecture, but also to the production of architectural theory. This is because it has the capacity to suspend and layer the reading of moving image and text, giving the reader-spectator an active role in engaging the theoretical content in an expanded audiovisual and speculative realm.

There are increasing levels of engagement with filmmaking in the field of architecture. As an architect-filmmaker and a digital anthropologist working collaboratively, we have turned to the work of anthropological documentary filmmakers who have led the way in audiovisual research, and been embraced by their academic community. Our interest is in the operative modes of anthropological audiovisual research, which explore a range of new visual aesthetics from realism and artistic experimentation to abstraction. By closely examining works by David McDougall, Sarah Pink, and Kathryn Ramey, we aim to reveal potential ways to expand the writing practice of theory beyond the readable into the audible, visible, and performative; the redefinition of particular processes of filmmaking here constitutes new forms of architectural theory. By foregrounding audiovisual modes, the anthropologist-filmmaker facilitates an encounter between the audience and a set of textual-visual languages that can be layered and decoded in different orders, or disorders. This encounter offers narrativebased, audiovisual voices, contrary to the tradition of academized author(ity), which becomes the new constituent of architectural theory.

\section{Lessons from Visual Anthropology about Authority and the Audience}

According to Stephen Hughes, David MacDougall drew the academic community of anthropology's attention to the issue of "the audience" in his keynote address at the Royal Anthropological Institute's

Ethnographic Film Festival in 1990. According to Hughes, "the audience" is both a theoretical issue and a methodological problem. ${ }^{17}$ Hughes cites film, media studies, and cultural studies as having made attempts to address audience reception as a central issue in understanding theory. He thus prompts a new wave of debate regarding the dominance of text over other forms of communication, continuing the argument made by Margaret Mead in 1975 of the need for anthropology to wrench itself away from the addiction to words. ${ }^{18}$ In doing so, Mead established a legitimacy of audiovisual representation as a mode of anthropological inquiry which became known as media anthropology. ${ }^{19}$ However, when MacDougall was speaking in 1990, he highlighted the importance of taking into consideration the way the audience makes sense of ethnographic films, advocating his position on film as a three-way encounter between filmmaker, subject, and audience. By making this point in an anthropological context, he was also flagging up a broader intellectual shift that W. J. T. Mitchell identified as a "pictorial turn" in the Western production of knowledge. ${ }^{20}$ This signaled a move away from 
the linguistic and textual privileges in structuralism, semiotics, ${ }^{21}$ poststructuralism, and deconstruction, reinforced also by Rancière. ${ }^{22}$

The heightened crisis of representation in the discipline of anthropology, epitomized by the seminal text Writing Cultures: The Politics and Poetics of Ethnography, raised an awareness that academic anthropologists do not have a monopoly on the production and interpretation of visual media, nor do they have the final word in the exchange of ideas between the "Us" and the "Them" in visual representation. ${ }^{23}$ This new politics of representation has helped to articulate a new and crucial distinction between "using a medium and studying how a medium is used." 24 Hughes writes:

In a reframing similar to what the crisis of representation had provoked among anthropologists, the problem for media and cultural studies shifted from trying to grasp the realities of audiences to asking political and epistemological questions about what constitutes the authority to make claims about the audience. ${ }^{25}$

The encounter with audiences has long been an important part of the intellectual process of filmmaking. Documentary theorist Bill Nichols proposes that the documentary filmmaker adopts a certain kind of approach to his or her work that ultimately defines the end product, which in turn determines the range of possible ways that audiences are permitted to receive the work. ${ }^{26} \mathrm{He}$ describes these modes of documentary as being expository, observational, poetic, performative, reflexive, participatory and interactive. The expository mode would find an equivalent in the traditional written form of an academic essay which presents an argument backed up by evidence. ${ }^{27}$ Comparison of approaches by documentary filmmakers using the expository mode shows the accentuation of the authorial position of filmmakers. When the expository mode is substituted by another mode, or other modes are added to the film, we find that it will affect the way the material is received by the audience. An observational documentary will have an emphasis on the passing of the world whilst prioritizing its subject; it will show, but not tell. This contrasts dramatically with the expository "voice of God," a familiar mode used on television to show and tell derived from literary argument. Whilst filmmaking has borrowed and imitated literary styles, it has also developed its own set of visual images and codes through which propositions might be constructed to promote alternative relationships between the audience and its subject matter. In some cases, the position of the filmmaker is offered as no more than incidental. In other cases, we engage with the subject matter in a more sensorial, experiential, interactive, and intuitive way. By exploring the ambiguity inherent in the exchange between audio and visual materials, non-expository documentaries have paralleled the art-house form of "essay film," which will be discussed below. ${ }^{28}$ Whichever mode of 
documentary is used, the publication of research projects by means of multimedia offers new possibilities to connect fragmented bodies to voices, to yield both new processes and new products.

As has been made apparent in the discussion on anthropological media and non-expository documentaries, the creation of new vocabularies by means of the new visual medium has not been explored enough in academic scholarship. In "The Body in Cinema," McDougall suggests that films in architecture constitute an experiential embodiment of ideas that moves the emphasis from the creator of knowledge to the spectator of knowledge. MacDougall alludes to the insights of Linda Williams when she says "viewing other people's experiences in films is not simply a matter of sharing them but of discovering autonomous bodily responses in ourselves that may differ from those we witness." ${ }^{29}$ MacDougall explains that "films allow us to go beyond culturally prescribed limits and glimpse the possibility of being more than we are. They stretch the boundaries of our consciousness and create affinities with bodies other than our own."30

\section{Making Visible Other Voices and Experiences}

Since the early 1990s, Pink has been at the forefront of digital visual anthropology through her publications and research practice. ${ }^{31}$ She examines the relationship between visual anthropology and digital media, and points out the challenges that digital media have presented to the traditions of making ethnographic films. ${ }^{32}$ She suggests that visual anthropology has a place in activism, such as in public forums based on Jean Rouch's notions of "shared anthropology." ${ }^{33}$ We are drawn to thoughts of shared agendas and shared ways of distributing and consuming visual documents. This approach links to the previous discussion on the corporeality of anthropological films pioneered by MacDougall. Pink writes of the need for visual anthropology to engage with multisensory experiences and establish the potential for substantial discussion about the move from the medium to the body. ${ }^{34}$ She calls for a "closer attention to the implications of engaging theoretical and methodological tools available for thinking about media through the senses in media scholarship" and for "focus on practice and the non-representational as part of a non-media-centric approach to media studies."

Pink's Pioneering Women's Worlds project (2000), Gender at Home (2004), and the more recent Energy and Digital Living Project (2014) ${ }^{36}$ examine domestic life through the research methodology of sensory ethnography by making videos of home tours designed specifically for the project. ${ }^{37}$ Real-time documentary video clips, in which Pink is audibly and visually present as a researcher, contribute to a theoretical position of sensory engagement between her body and other bodies in a shared space. Pink sees the inclusion of video and multimedia in publications as an important means for anthropology to make critical interventions in public. She envisages a multimedia anthropology that necessitates the 
use of audiovisual media as a form of analysis and enables coproduction between itself and other disciplines. ${ }^{38}$

In contrast, Ramey presents a creative, artistic cinematographic

research practice that produces documentaries and short fictional films as a form of non-chronological nor narrative-driven theory. ${ }^{39}$ Through her research into (mostly female) avant-garde filmmakers such as Chick Strand and Maya Deren, Ramey reveals how experimental film techniques can contribute to visual anthropology. She argues that these approaches to filmmaking not only provide theories about anthropology, but also they are crucially stand-alone artworks with aesthetic and poetic values. For Ramey, image-making in film is also a form of visual and sensorial research. ${ }^{40}$

In Ramey's videos, voices that are otherwise invisible become sensuously visible. Because avant-garde film "does not adhere to any standard in terms of length, style, or even format," its "artisanal practice" presents ethnography filmmakers with a new space of research that is attentive to subjects and the sensuous world. This is a new space of critical research practice that produces political and social commentary about culture..$^{41}$ As Arnd Schneider and Caterina Pasqualino contend in "Experimental Film and Anthropology," the "realist-narrative paradigm" that dominated visual anthropology has been challenged by avantgarde approaches such as in abstract, futurist, surrealist, absolute, and structuralist films employed by experimental filmmakers who can be regarded as anthropologists in their own right. ${ }^{42}$ By engaging with an experimental mode of practice, anthropologist-filmmakers like Ramey challenge the representation of conventional argument as a three-part narrative (exposition/introduction, complication/body, resolution/conclusion). The new modes of visual anthropology open up opportunities for new audiovisual languages that incorporate other disciplines from psychology, psychiatry, and behaviourism to kinesics in anthropological research. ${ }^{43}$

In Ramey's experimental video West: What I Know about Her (2012) (Figure 1), made with her then five-year-old son, the craft of audiovisual writing is applied to a historical anthropological project to achieve a poetic and visual abstraction. It is a documentary about Elizabeth Crandall Perry who is an adventurer, midwife, and distant ancestor of the filmmaker. ${ }^{44}$ Ramey uses the editing technique of montage to juxtapose images relating to Perry and her memory, which include clips of wood chopping (the creation of new settlements in new lands) and photographs of the expansive American landscape that held the viewer's prolonged gaze to reflect the scale of colonization and lost. Ramey experiments with written and audio narration, audio recordings, still and moving images and footage of theoretical connections between histories of place, landscape, culture, gender, and identity. More radical than Pink's direct cinema, Ramey's work presents a range of new practices and relations between the researchers of anthropology and 
landscape architecture, and their audiences through the new craft of audiovisual writing and reading.

\section{Film as Architectural Theory}

Theoreticians of architecture who use filmmaking as a medium of research and communication are rare but increasing in number; most produce case-study films of cities, architectures, or landscapes. The UK-based architectural filmmaker Monica Koeck's short film Left Behind (2009) is a cinematic, real-time, documentary-style study of Liverpool produced collaboratively with Richard Koeck's theoretical publications. This film as a form of practice-based research centers on the city of Liverpool and its buildings in relation to their urban image. ${ }^{45}$ Another example is the collaborative research on domesticity in Singaporean public housing by architectural theoretician and producer Lilian Chee and filmmaker Lei Wan Bin, which presents an architectural theory that intersects documentary-making and textual publication. ${ }^{46} \mathrm{~A}$ third example would be the filmmaker Patrick Keiller, who studied architecture before turning to filmmaking and who has presented architectural and social theories on London and its architecture since the early $1980 \mathrm{~s} .{ }^{47}$

The emerging field of film as architectural theory is expanding because architectural theoreticians began to explore and employ filmmaking practices outside of architecture, which in turn provoke new modes of crafting architectural theory. These filmic experimentations inform what constitutes architectural "writing" beyond the written page and limitations of text-based medium on the architectural theoretician. The filmic further informs the role and essence of the "essay film" in architecture. ${ }^{48}$ In "Translating the Essay into Film and Installation," Nora M. Alter discusses "a mode of audio-visual production, loosely called the 'essay film' [that] has proliferated in recent years within the disciplines of film and fine art" [... and is] sometimes referred to as "filmed philosophy."'49 Framed by what it means "to essay" or "to assay," the essay film, as first used and defined by Hans Richter in his 1940 essay "Der Filmessay: eine neue Form des Dokumentarfilm" 50 is a form of filmmaking that, according to Alter, "produces complex thoughtreflections that are not necessarily bound to reality. [...] The essay film, [Richter] argues, allows the filmmaker to transgress the rules and parameters of the traditional documentary practice, granting the imagination with all its artistic potentiality free reign. ${ }^{51}$

Here two operatives of anthropological theory filmmaking demonstrate how new audiovisual spaces, languages, and codes broke down traditional forms of knowledge. The audiovisual films discussed suggest that there is a place for a non-linguistic understanding of theory within the discipline of anthropology, and we contend that architecture too has begun to use new forms of production to create new reflection and understanding of itself. Barbara Glowczewski argues that hypermedia offers a form of representation that reflects how people think and read better than the text-based media. She states: 
Non-linear or reticular thinking most stresses the fact that there is no centrality to the whole, but a multipolar view from each recomposed network [...] allowing the emergence of meanings and performances, encounters, creations as new original autonomous flows. ${ }^{52}$

New digital technologies, from the digital camera, computer, mobile phone to the World Wide Web, have brought advanced audiovisual capabilities to the realm of architectural theory. "[As a] machine for image-making - [the digital camera] produces a supplement to pure 'record' that is different to the supplement that is also produced through the affective nature of the pen, the typewriter and the computer - the machines for writing." 53 This defines the new instrument of writing for the filmmaker-anthropologist or filmmaker-architectural theorists in their new modes of practice-based research. When writing about his film series “The Doon School Chronicles," MacDougall describes how the availability of digital video recording changes the way he thinks of the making of a film. It becomes simply a matter of using the video camera as a means of investigation across a much longer period of time to create hybrid films:

I realized I did not have to make a "film" as it was understood in any conventional sense. Instead I began to think about a longterm study of the school using a video camera as my means of inquiry. What would emerge from this I did not know, and therein lay one of its attractions. ${ }^{54}$

In the hands of a critical architectural thinker, "film as theory" can widen an architectural theoretician's mode of practice and suitable forms of publication. Depending on the balance between the use of written text, voiceover, audio, still, and moving image, films can also broaden participatory knowledge and engage with wider cultures. Based on this principle, film as architectural theory has the potential to present new forms of communal and discursive authorship, readership, and viewership about architecture. Beyond the skepticism projected by those talking about "theoretical meltdowns," the exploration and pursuit of film as architectural theory engages with the diversity of voices in a culture of hyper-modernity and accepts the positive impact of forums of digital exchange on society at large. The practice of architectural theory thus can break away from the limit of internalized institutional consumption and creative restriction.

Igea Troiani is an academic, architect, and filmmaker. She is founder of the film company Caryatid Films and the architectural practice Original Field of Architecture Ltd. With Hugh Campbell she co-edited the "Architecture Film" issue of Architecture and Culture (March 2015). She is currently co-editing the books Architecture Filmmaking and Visual Methodologies in Architectural Research, both due out in 2016. 
Alison Kahn is a specialist in visual and material anthropology. She is interested in the use of film as a tool for research and promotes an interdisciplinary and cross-cultural understanding of visual culture. She trained as a documentary filmmaker, museum curator, and anthropologist at Goldsmiths College, the University of London, and the University of Oxford.

\section{Acknowledgements}

The authors thank Kathryn Ramey for permission to use stills from her video here.

\section{Notes}

1 Christopher Hight, "Meeting the New Boss: After the Death of Theory," Architectural Design 79, no. 1 (2009): 40-5.

2 Helen Castle, "Editorial" to "Theoretical Meltdowns," Architectural Design 79, no. 1 (2009): 4-5, at 4.

3 Hight, "Meeting the New Boss," referring to the writings of Michael Speaks.

4 Stan Allen, Practice: Architecture, Technique and Representation (Amsterdam: G\&B Arts International, 2000).

5 Mark Wigley, in an interview with Stuart Mason Dambrot, consilientist and futurist; "Mark Wigley: Architectural Theory: A View of Structure," on Critical Thought TV, https://www.youtube.com/ watch? $v=107 \mathrm{~m} 4 \mathrm{~d} \_07 \mathrm{yw}$ (accessed August 30, 2016).

6 Hight, "Meeting the New Boss."

7 Luigi Puglisi Prestinenza, "Anything Goes," Architectural Design, 79, no. 1 (2009): 6-12. Prestinenza does give a warning, though: "However, in all cases, when we broaden the frontiers of opportunities and freedom, there is also an increase in the danger of the irrelevant, the arbitrary and the banal. The weaker the system of disciplinary rules, the more we require a strong orientation that can no longer depend on simple value judgement"; 11 .

8 Roland Barthes, "The Death of the Author," in Image Music Text (Illinois: Fontana, 1993).

9 Gillian Rose, Visual Methodologies: An Introduction to Researching with Visual Materials, 3rd ed. (London: Sage, 2012).

10 Giuseppina Mecchia, "The Future of the Image [Review]," symploke, 16, nos. 1-2 (2008): 313-16; Jacques Rancière.
The Future of the Image, ed. and trans. Gregory Elliot (London: Verso, 2007).

11 Rancière, Future of the Image, 3.

12 lbid., 8.

13 Ibid., 11. Images differ from being a naked image (that records reality), an ostensive image (one that influences through its presence but is without signification), or a metaphorical image (one where its operation of production relates the operation of the imaginary).

14 Mario Carpo, Architecture in the Age of Printing: Orality, Writing, Typography, and Printed Images in the History of Architectural Theory (Cambridge, MA: MIT Press, 2001), 6.

15 Juhani Pallasmaa, The Eyes of the Skin: Architecture and the Senses (Chichester: Wiley-Academy, 2005), 13.

16 Ibid., 44.

17 Stephen P. Hughes, "Anthropology and the Problem of Audience Reception," in Made to be Seen: Perspectives on the History of Visual Anthropology, ed. Marcus Banks and Jay Ruby (Chicago, IL: University of Chicago Press, 2011), 288-9.

18 Margaret Mead with Ken Heyman, World Enough: Rethinking the Future (Boston, MA: Little Brown, 1975).

19 Hughes, "Anthropology and the Problem of Audience Reception," 289.

20 W. J. T. Mitchell, Picture Theory (Chicago, IL: University of Chicago Press, 1995), 11-13.

21 Mead is recognized for bringing the word "semiotics" into common use.

22 The film theorist Barry Salt would agree that the privileging of textual analysis over the making of films in the teaching of film and media studies' degrees polarized what was once a healthy theoretical relationship between 
process and product; Barry Salt, Film Style, Technology, History and Analysis (London: Starwood, 2009).

23 George E. Marcus and James Clifford, Writing Culture: The Poetics and Politics of Ethnography (Berkeley: University of California Press, 1986).

24 Hughes, "Anthropology and the Problem of Audience Reception," 291.

25 Ibid., 292.

26 Bill Nichols, Introduction to Documentary (Bloomington: Indiana University Press, 2010).

27 Davis Guggenheim, dir., An Inconvenient Truth (Lawrence Bender Productions, 2006).

28 Nora M. Alter, "Translating the Essay into Film and Installation," Journal of Visual Culture 6, no. 1 (2007): 44.

29 Williams, quoted in David MacDougall, The Corporeal Image: Film, Ethnography, and the Senses (Princeton, NJ: Princeton University Press, 2006), 15.

30 Ibid., 16-17.

31 Sarah Pink, Doing Visual Ethnography: Images, Media and Representation in Research (London: Sage, 2007[2001]); Simone Abram and Sarah Pink, eds., Media, Anthropology and Public Engagement (New York: Berghahn, 2015).

32 Sarah Pink, "Digital Visual Anthropology: Potential and Challenges," in Banks and Ruby, Made to be Seen, 209-33.

33 Ibid.

34 Sarah Pink, "Approaching Media through the Senses: Between Experience and Representation," in Media International Australia, 154 (February 2015): 2-3, http://www.uq.edu.au/mia/2015issues\#154/.

35 Ibid.

36 See Sarah Pink's Energy and Digital Living project (2014). For full videos, see http://energyanddigitalliving.com (accessed August 30, 2016). Due to the inclusion of participants who we were unable to contact, we have not been able to include a sequence of stills from Pink's videos.

37 See http://energyanddigitalliving.com (accessed August 30, 2016).

38 Pink, "Digital Visual Anthropology," 215.

39 Kathryn Ramey, "Productive Dissonance and Sensuous Image-Making: Visual Anthropology and Experimental Film," in Banks and Ruby, Made to be Seen, 256-87.

40 Ramey, "Productive Dissonance and Sensuous Image-Making," 257; see also Catherine Russell, Experimental

Ethnography: The Work of Film in the Age of Video (Durham, NC: Duke University Press, 1999). "In her 1999 tome Experimental Ethnography, Catherine Russell purports to connect experimental and ethnographic film through textual and comparative analysis, showing how some experimental filmmakers work is ethnographic and how some films by anthropologists are experimental or can be viewed through an avant-garde lens."

41 Ramey, "Productive Dissonance and Sensuous Image-Making," 258, 259.

42 Arnd Schneider and Caterina Pasqualino, eds., Experimental Film and Anthropology (London: Bloomsbury, 2014), 1.

43 Ibid.

44 See http://rameyfilms.com/movies.html (accessed August 30, 2016).

45 Richard Koeck and Les Roberts, eds., The City and the Moving Image: Urban Projections (Basingstoke: Palgrave Macmillan, 2010); Richard Koeck, Cinescapes: Cinematic Spaces in Architecture and Cities (London: Routledge, 2012).

46 Lei Yuan Bin, dir., and Lilian Chee, exec. prod., 03-FLATS ( 13littlepictures, 2014); Lilian Chee, "Domesticity + Home: Reframing Narratives, Reforming Boundaries," in Lilian Chee and M. S.-M. P. Park, eds., Home + Bound: Narratives of Domesticity in Singapore and Beyond (Singapore: Center for the Advanced Studies in Architecture, National University of Singapore, 2013); Lilian Chee, "The Public-Private Interior: Constructing the Modern Domestic Interior in Singapore's Public Housing," in G. Brooker and L. Weinthal, eds., The Handbook of Interior Architecture and Design (London: Bloomsbury, 2013), 199-212.

47 Patrick Keiller, dir., London (1994); Robinson in Space (1997); The Dilapidated Dwelling (2000); Robinson in Ruins (2010). See also Patrick Keiller, Robinson in Space (London: BBC Printers, 1999); idem, The Possibility of Life's Survival on the Planet (London: Tate Publ., 2012); and idem, The View from the Train: Cities and Other Landscapes (London: Verso, 2014).

48 The word "essay" derives from the French essayer, "to try" or "to attempt." In English "essay" first meant "a trial" or "an attempt," and this is still an alternative meaning.

\section{6}

Film as Architectural Theory Igea Troiani and Alison Kahn 
49 Alter, "Translating the Essay into Film and Installation," 44.

50 Hans Richter, "Der Filmessay: Eine neue Form des Dokumentarfilms" (The Film Essay: A New Form of Documentary Film) [April 24, 1940], in Schreiben Bilder Sprechen: Texte zum essayistischen Film, ed. Christa Blümlinger and Constantin Wulff (Vienna: Sonderzahl, 1992), 195-8.

51 Nora M. Alter, "Memory Essays," in Stuff It: The Video Essay in the Digital Age, ed. Ursual Biemann (Zurich: Voldemeer, 2003), 12-23, at 14. See also Timothy Corrigan, The Essay Film: From Montaigne, After Marker (Oxford: Oxford University Press: Oxford, 2011); and

\section{References}

- Abram, Simone, and Sarah Pink (eds.). 2015. Media, Anthropology and Public Engagement. New York: Berghahn Books.

- Allen, Stan. 2000. Practice: Architecture, Technique and Representation. Amsterdam: G\&B Arts International.

- Alter, Nora M. 2003. "Memory Essays." In Stuff it: The Video Essay in the Digital Age, edited by Ursual Biemann, 12-23. Zurich: Edition Voldemeer.

- Alter, Nora M. 2007. "Translating the Essay into Film and Installation." Journal of Visual Culture, 6, no. 1:44-57.

- Banks, Marcus, and Jay Ruby (eds.). 2011. Made to be Seen: Perspectives on the History of Visual Anthropology. Chicago, IL: University of Chicago Press.

- Barthes, Roland 1993. "The Death of the Author." In Text, new ed, edited by Roland Barthes and Image Music. Illinois: Fontana Press.

- Blake, Tara, and Janet Harbord. 2008. "Typewriters, Cameras and Love affairs: The Fateful Haunting of Margaret Mead." Journal of Media Practice, 9, no. 3: 215-227.

- Carpo, Mario. 2001. Architecture in the Age of Printing: Orality, Writing, Typography, and Printed Images in the History of Architectural Theory. Cambridge, MA: MIT Press.

- Castle, Helen. 2009. "Editorial," 'Theoretical Meltdowns." Architectural Design, 79, no. 6: 4-5.

- Chee, L. 2013. “Domesticity + Home: Reframing Narratives, Reforming Boundaries." In Home + Bound: Narratives of Domesticity in Singapore and Beyond, edited by L. Chee and M. S.-M. P. Park.
Laura Rascaroli, The Personal Camera: Subjective Cinema and the Essay Film (Wallflower, 2009).

52 Barbara Glowczewski, "Lines and Criss-Crossings: Hyperlinks in Australian Indigenous Narratives," Media International Australia, 116 (2005): 24-35. at 28.

53 Tara Blake and Janet Harbord, "Typewriters, Cameras and Love Affairs: The Fateful Haunting of Margaret Mead," Journal of Media Practice, 9, no. 3 (2008): 226.

54 MacDougall, quoted in Pink, "Digital Visual Anthropology," 221.

Singapore: Center for the Advanced Studies in Architecture, National University of Singapore.

- Chee, L. 2013. “The Public Private Interior: Constructing the Modern Domestic Interior in Singapore's Public Housing." In The Handbook of Interior Architecture and Design, edited by G. Brooker and L. Weinthal, 199-212. London: Bloomsbury.

- Corrigan, Timothy. 2011. The Essay Film: From Montaigne, After Marker. Oxford: Oxford University Press.

- Glowczewski, Barbara. 2005. "Lines and Criss-Crossings: Hyperlinks in Australian Indigenous Narratives." Media International Australia, 116: 24-35.

- Hight, Christopher. 2009. "Meeting the New Boss: After the Death of Theory." Architectural Design, 79, no. 1: 40-45.

- Hughes, Stephen Putnam. 2011. "Anthropology and the Problem of Audience Reception." In Made to be Seen: Perspectives on the History of Visual Anthropology, edited by Marcus Banks and Jay Ruby, 288-312. Chicago, IL: University of Chicago Press.

- Keiller, Patrick. 1999. Robinson in Space. London: BBC Printers Limited.

- Keiller, Patrick. 2012. The Possibility of Life's Survival on the Planet. London: Tate Publishing.

- Keiller, Patrick. 2014. The View from the Train: Cities and Other Landscapes. London: Verso.

- Koeck, Richard, and Les Roberts (eds.). 2010. The City and the Moving Image: Urban Projections. Basingstoke: Palgrave Macmillan. 
- Koeck, Richard. 2012. Cine-scapes: Cinematic Spaces in Architecture and Cities. London: Routledge.

- MacDougall, David. 2006. The Corporeal Image: Film, Ethnography, and the Senses. Princeton, NJ: Princeton University Press.

- Marcus, George E., and James Clifford. 1986. Writing Culture: The Poetics and Politics of Ethnography. Berkeley, CA and London: University of California Press.

- Mead, Margaret with Ken Heyman. 1975. World Enough: Rethinking the Future. Boston, MA: Little Brown and Company.

- Mecchia, Giuseppina. 2008. "The Future of the Image," symploke, 16, nos. 1-2: 313-316.

- Mitchell,W.J.T. 1995. Picture Theory. Chicago, IL: University of Chicago Press.

- Nichols, Bill. 2010. Introduction to Documentary. 2nd ed. Bloomington: Indiana University Press.

- Pallasmaa, Juhani. 2005. The Eyes of the Skin: Architecture and the Senses. Chichester: Wiley-Academy.

- Pink, Sarah. [2001] 2007. Doing Visual Ethnography: Images, Media and Representation in Research. London: Sage.

- Pink, Sarah. 2011. "Digital Visual Anthropology: Potential and Challenges." In Made to be Seen: Perspectives on the History of Visual Anthropology, edited by Marcus Banks and Jay Ruby, 209-233. Chicago, IL: University of Chicago Press.

- Pink, Sarah. 2015. "Approaching Media through the Senses: Between Experience and Representation." Media International Australia 154. Available online: http:// www.uq.edu.au/mia/2015-issues\#154

\section{Videography/Filmography}

- Guggenheim, Davis (dir.). 2006. An Inconvenient Truth. Lawrence Bender Productions.

- Lei Yuan Bin (dir.) and Lillian Chee (exec. prod.). 2014.03-FLATS. 13littlepictures.

- Keiller, Patrick, (dir.). 1994. London.

- Keiller, Patrick, (dir.). 1997. Robinson in Space.

- Keiller, Patrick, (dir.). 2000. The Dilapidated Dwelling.

- Keiller, Patrick, (dir.). 2010. Robinson in Ruins.

- Pink, Sarah. All videos for Energy and Digital Living project (2014) at http://
- Puglisi Luigi Prestinenza. 2009. "Anything Goes," Architectural Design, 79, no.1: 6-12.

- Ramey, Kathryn. 2011. "Productive Dissonance and Sensuous Image-Making: Visual Anthropology and Experimental Film." In Made to be Seen: Perspectives on the History of Visual Anthropology, edited by Marcus Banks and Jay Ruby, 256-287. Chicago, IL: University of Chicago Press.

- Rancière, Jacques. 2007. The Future of the Image, edited and translated by Gregory Elliot 2007. London and New York: Verso.

- Rascaroli, Laura. 2009. The Personal Camera: Subjective Cinema and the Essay Film. New York: Wallflower Press.

- Richter, Hans. 1992 [1940] "Der Filmessay: Eine neue Form des Dokumentarfilms" [The Film Essay: A New Form of Documentary Film]. In Christa Blümlinger and Constantin Wulff, Schreiben Bilder Sprechen: Texte zum essayistischen Film, 195-198. Vienna: Sonderzahl [24 April 1940].

- Rose, Gillian. 2012. Visual Methodologies: an Introduction to Researching with Visual Materials. 3rd ed. London: Sage.

- Russell, Catherine. 1999. Experimental Ethnography: The Work of Film in the Age of Video. Durham, NC: Duke University Press.

- Salt, Barry. 2009. Film Style, Technology, History and Analysis 3rd ed. London: Starwood.

- Schneider, Arnd, and Pasqualino, Caterina (eds.). 2014. Experimental Film and Anthropology. London: Bloomsbury.

energyanddigitalliving.com/, accessed 30 August 2016

- Ramey, Kathryn (dir.). 2012. WEST: What I Know about Her. https://www.youtube. com/watch?v=euuQGqfF7Tg (accessed 30 August 2016).

- Wigley, Mark in an interview with Stuart Mason Dambrot, "Mark Wigley: Architectural Theory: A View of Structure" on Critical Thought TV, https://www. youtube.com/watch?v=107m4d_07yw, (accessed 30 August 2016)

\section{8}

Film as Architectural Theory Igea Troiani and Alison Kahn 